\title{
What is a Walkable Place? The Walkability Debate in Urban Design
}

\section{Citation}

Forsyth, Ann. 2015. What is a walkable place? The walkability debate in urban design. Urban Design International 20, no.4: 274-292.

\section{Published Version}

10.1057/udi.2015.22

\section{Permanent link}

http://nrs.harvard.edu/urn-3:HUL.InstRepos:29663388

\section{Terms of Use}

This article was downloaded from Harvard University's DASH repository, and is made available under the terms and conditions applicable to Open Access Policy Articles, as set forth at http:// nrs.harvard.edu/urn-3:HUL.InstRepos:dash.current.terms-of-use\#OAP

\section{Share Your Story}

The Harvard community has made this article openly available.

Please share how this access benefits you. Submit a story.

Accessibility 


\title{
What is a Walkable Place? The Walkability Debate in Urban Design
}

2015 A. Forsyth. What is a Walkable Place? The Walkability Debate in Urban Design. Urban Design International 20, 4: 274-292.

\begin{abstract}
What exactly is meant by the term "walkability"? In professional, research, and public debates the term is used to refer to several quite different kinds of phenomena. Some discussions focus on environmental features or means of making walkable environments, including areas being traversable, compact, physically-enticing, and safe. Others deal with outcomes potentially fostered by such environments, such as making places lively, enhancing sustainable transportation options, and inducing exercise. Finally some use the term walkability as a proxy for better design whether composed of multiple, measurable dimensions or providing a holistic solution to urban problems. This review both problematizes the idea of walkability and proposes a conceptual framework distinguishing these definitions. This matters for urban design, because what is considered a walkable place varies substantially between definitions leading to substantially different designs. By mapping the range of definitions, this review highlights potential conflicts been forms of walkability.
\end{abstract}

Key Words: walkability, pedestrian, vitality

\section{What is a Walkable Place? \\ The Walkability Debate in Urban Design}

\section{The Problem of Walkability}

There is currently much talk about creating walkable environments and improving walkability. Such strategies are meant to solve numerous problems from the obesity crisis and a lack of central city vibrancy to traffic congestion, environmental injustice, and social isolation. However, what exactly is meant by "walkability" and the related idea of the walkable place? This paper reviews the English-language literature on walkability-from research, practice, and popular discussions-and proposes that the term is used to refer to several quite different kinds of phenomena. Some discussions of walkability focus on the means or conditions by which walking is enabled, including areas being traversable, compact, physically-enticing, or safe. Others propose that walkability is about the outcomes or performance of such walkable environments, such as making places lively and sociable, enhancing transportation options, or inducing exercise. A final set of discussions uses the term walkability as a proxy for better urban places-with some paying attention to walkability being multidimensional and measurable and others proposing that enhancing walkability provides a holistic solution to a variety of urban problems. 
This review problematizes the idea of walkability and draws out implications for debates in urban design. It first explores why the confusion about the term and the outcomes it can produce is problematic, not least because some of the outcomes conflict. It then proposes nine different themes dealt with in definitions. These themes imply varying approaches to improving walkability, from the compact city and New Urbanism to Radburn planning, safe routes to school, and trail-based approaches. It concludes by proposing two approaches to defining physical walkability that nest into a larger conceptualization of the term. First is a minimal definition based on having basic conditions for walking (traversability), combined with closeness and minimal safety. Second, the term walkability can be more clearly specified in terms of purpose. In doing this, scholars and practitioners would also more clearly distinguish between walkability features or means, walkability outcomes, and walkability as a proxy for improved, or at least measurable, place-making.

In addition, more can be done in urban design to consider the many factors beyond physical components that come together to make a walkable place however it is defined. These include pricing of relevant alternatives (from automobile use to recreation centers), policies and programs supporting walking, and characteristics of the population (preferences, motivations, demographics, etc.). While the fields of health and transportation typically do consider these issues, they are not always prominent in urban design discussions.

\section{Why Bother to Define Walkability?}

The term walkable has been in use since at least the $18^{\text {th }}$ century (Oxford English Dictionary 2013). In contrast, walkability is a more recent term relatively rarely defined in dictionaries but in common use. If people are using the terms successfully, why bother to more clearly define them? Conflicting definitions cause problems, however, as they affect how people try to create walkable places in practice, measure environmental walkability, and assess the costs and benefits of creating walkable environments. Practitioners and researchers may talk with great conviction about how to make environments more walkable, but could well be proposing conflicting solutions. The lack of clarity also makes it difficult to a develop theory to guide practice (Caplan and Nelson 1973). ${ }^{i}$

\section{Identifying Walkability}

Review Approach

To explore the issue of walkability, Google, Google Scholar, Bing, and the related Microsoft Academic Search were searched for the terms "walkability" and "walkable." The specific phrases "define walkability," "define walkable," or "walkability definition" were also included in various combinations and orders. Google has been shown to be superior to others in locating publications (Hodge and Lacasse 2011), though recent changes in Bing made it a viable alternative. Key web sites were identified in these early searches and from general knowledge of the field - for example, the Active Living Research web site and walkscore.com. Works cited in articles, reports, and books identified in these earlier searches were also located. Other sources included dictionaries and professional literature on pedestrians (including reports and pedestrian plans). Some meanings are more prominent in public debates or practice, others in research, but the boundary between research work and practice is quite porous. 
Given that the terms walkable and walkability are very widely used in such areas as the news media and public meetings, the works cited in this paper are not an exhaustive list. Rather the search concluded when there were no new definitions emerging from additional investigation. The specific works included in this paper thus typify the overall range of definitions. It was not possible to quantitatively analyze which uses were most common since such assessments would be too sensitive to which literatures were included-research reports and articles, professional and media publications, and/or more speculative design work.

In health, one of the fields investigating walkability, a common format for conducting a literature review is the systematic review where the gold standard for such reviews aims to identify, analyze, and synthesize empirical research studies valuing rigorous quantitative study designs (Evans and Kowanko 2000; Callahan 2014). There are, however, many other forms of literature review (Booth et al. 2012, 22). This paper's approach is "interpretive" focusing on literature relevant to identifying the range of definitions in use (Barnett-Page and Thomas 2009). The final aim of such a review is a conceptualization or theory, grounded in the literature to identify themes and make an argument about their relationships (Dixon-Woods et al. 2006). Indeed, one of the motivations for this paper was a frustration that systematic reviews of the literature on aspects of walkability often come up with a set of very mixed findings because the definitions of walkability vary among studies. When practitioners, who may have yet another conceptualization of walkability, then try to apply the findings to design and planning proposals, there are further problems. By mapping out the range of definitions, this review can help provide a more specific language for future comparisons and proposals.

This review was able to build on some earlier work. One prior article had directly, and at length, tackled the issue of defining walkability, providing a historical and thematic overview of pedestrian planning (Lo 2009). Lo reviewed and critiqued transportation guidelines and analyses, outlined measures such as level of service or walkability indices, examined walkability planning in the context of multimodal transportation, described supports such as aesthetics, and explored proposed outcomes such as sociability and improved health (Lo 2009). A major focus of Lo's very useful paper was on measuring walkability; Lo was also critical of conventional transportation planning that, for example, proposed in the tradition of automotive level of service (LOS) calculations that lower densities of pedestrians were better (p. 163). As walkability discussions have flourished, the range of uses of the term has increased. It seemed time to re-address this issue and to expand beyond professional debates in transportation that was a major, though not exclusive, focus of Lo's paper.

\section{Key Themes or Dimensions}

The first cluster of definitions includes themes or dimensions related to the community environment, some of the means for creating walkability.

- Traversable environments have the basic physical conditionsto allow people to get from one place to another without major impediments, for example, relatively smooth paths.

- Compact places provide short distances to destinations for those who are walking for utility. 
- Several different dimensions are key to places being safe for walking--perceived and actual crime and perceived and actual traffic safety. Both are about potential harm to the person.

- Physically-enticing environments have full pedestrian facilities such as sidewalks or paths, marked pedestrian crossings, appropriate lighting and street furniture, useful signage, and street trees. They may also include interesting architecture, pleasant views, and abundant services attractive to those who have other choices for getting around and getting exercise.

The second set of definitions relate to perceived outcomes of walking.

- A walkable environment is often attractive because it is lively and sociable--pleasant, clean, and full of interesting people. Such definitions are much used in relation to shopping areas and mixed-use neighborhoods.

- In other cases, walkability is seen as a way to achieve both the environmental preservation and social equity components of sustainable urban form providing sustainable transportation options. This both saves energy and provides opportunities for those who can't use cars because of age, income, or disability.

- Many search for an exercise-inducing environment with features that lead to higher than average levels of walking either in total or for transportation or exercise.

Finally, walkability of is often used as a kind of proxy for better design. These proxies involve compilations of dimensions and very broad claims about outcomes. While it is certainly possible to criticize them as definitions, I include them because they are in common use as definitions of walkability.

- For some, walkability is multidimensional in terms of means and these dimensions are measureable. This kind of definition creates indicators of the conditions of walkability akin to definitions of livability or development based on indicators.

- Last, walkability is in many cases a way of talking about environments that are simply better-with walkability representing a holistic solution to improving urban areasslower paced, more human scaled, healthier, and happier. This encompasses many of the other definitions in an integrated package that is less about walking as such and more about a generally good place to be.

This is a listing of definitions in the literature, not a hierarchy. It is, however, possible to create a hierarchy as definitions in the first list are typically preconditions for those in the second, and they are combined in the third. Figure 1 demonstrates one way to conceptualize these relationships between themes and their associated specific definitions based on means, outcomes, and as proxies. The top of the chart includes minimum means or conditions and the bottom focuses more on outcomes. The right show how these are combined in the proxy measures. Basically all definitions include the dimensions at the top (compactness, traversability, safety), including the physically-enticing theme. However, in the literature, except for those explicitly looking at issues of hierarchy (e.g. Alfonzo 2005; Methorst et al. 2010), walkability is rarely seen in this way. People instead favor one or two of the definitions, using the same terms (walkable, walkability) to mean quite different things. 
Figure 1: Framework Linking Definitions of Walkability and Walkable Places

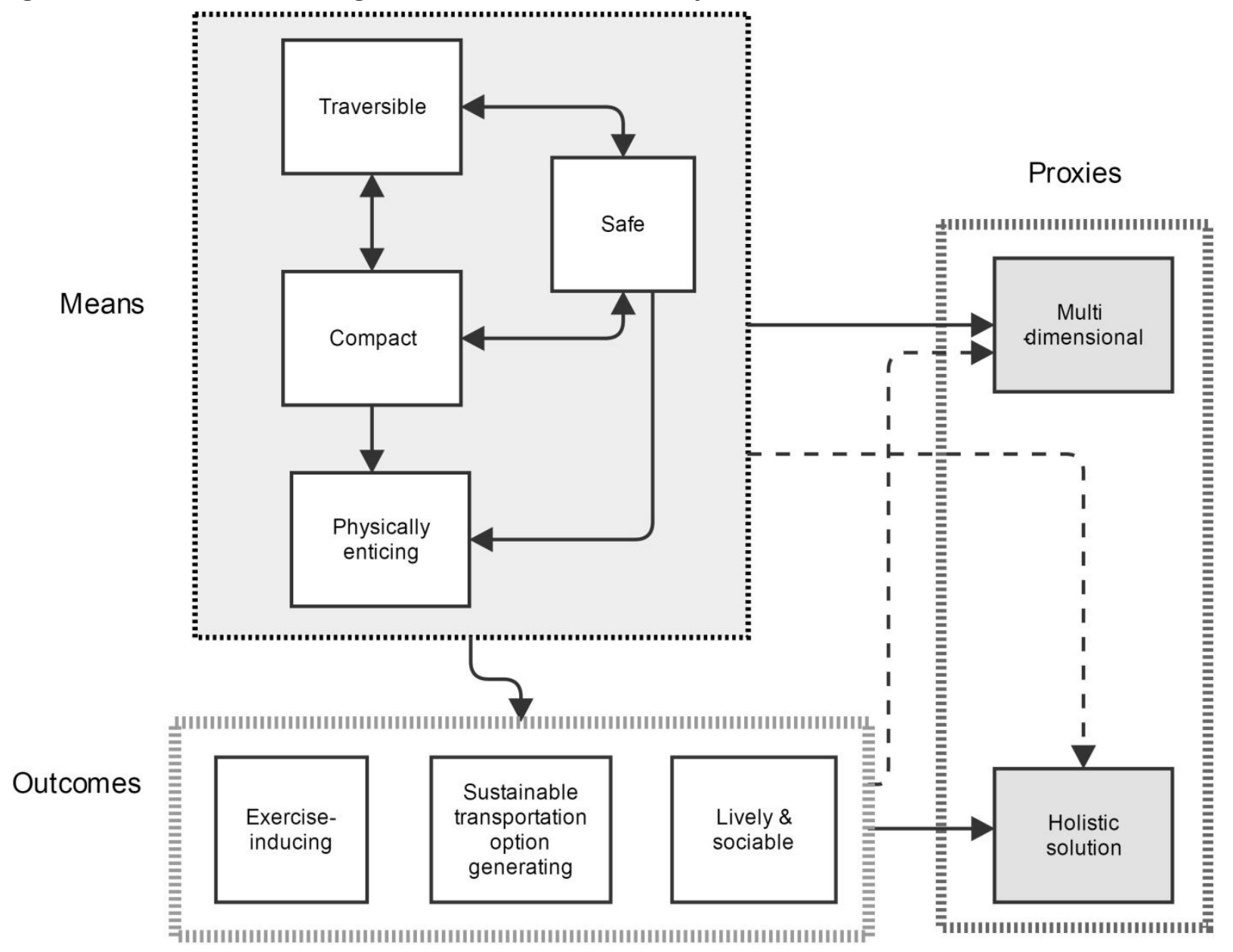

Figure 2 demonstrates how these themes map onto specific kinds of places. Environments like the one in image 1 are classic "walkable" places and widely promoted as such, although depending on the location and population, there may be more general liveliness than walking (Zook et al. 2012). In contrast, a great deal of walking occurs in places like those illustrated in the remaining photos. Image 2 shows women at lunch time walking in a park for exercise; the environment is quite different to the kind of place that supports walking for transportation. Image 3 illustrates a woman and children in a low-income new town walking in the central shopping district. It demonstrates a more minimal set of supports for walking including closeness and destinations but lacks some of the physical characteristics (street furniture, plantings) many associate with walkability. Image 4 captures pedestrians taking a shortcut, using a major pedestrian path that has, however, very few of the conditions or outcomes often associated with walkability in the literature. 


\section{Figure 2: Examples of Places Demonstrating Different Dimensions or Themes}

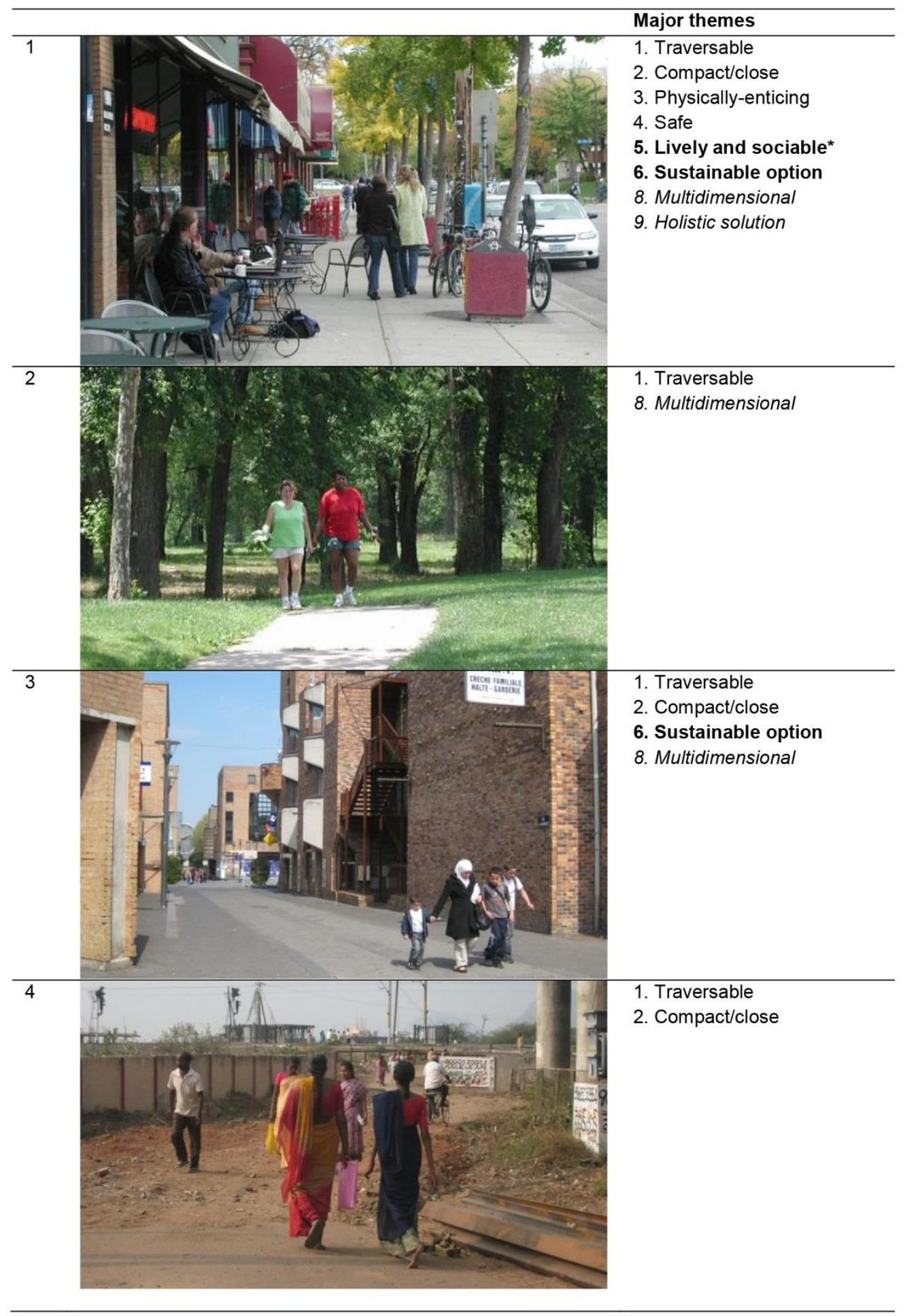

Locations: 1. Minneapolis, MN (in a college area); 2. Columbus, Indiana; 3. Paris, France (in a suburban new town); 4. Vijayawada, India (shortcut across rail line). Photos by author.

* Bold themes are outcomes; standard fonts are means or conditions; italics are proxies. Only major themes are listed; others may also be present. 
Of course many authors are not as precise as the listing of nine distinct dimensions would indicate. There is also some overlap among the definitions. For example, walkability as a holistic solution typically also involves creating lively and sociable places. Others do not explicitly define the term walkability, but rather imply a definition within a description. However, these features and outcomes together map the range of ways that academics, practitioners, advocates, and the public talk and write about walkability.

\section{Related Concepts}

It is also important to note the overlap between walkability and related terms (Lo 2009). Older terms that overlap substantially with walkability are pedestrian-oriented planning or pedestrian-oriented places. The term pedestrian is likely to be defined in legislation while walkability is not. Pedestrians certainly walk, but many regulations define the term more broadly to include people in wheelchairs and even, in some cases, those standing and not moving (Lo 2009, 146).

Some of the confusion over walkability is due to the issue of purposes and motivations. Walking can be done for many purposes such as transportation, exercise, and recreation. However, such purposes are often mixed, for example "walking around the lake to buy the paper" (Forsyth and Krizek 2010). Further, each purpose may have a different underlying motivation. For example, exercise or recreational walking may be done for stress reduction, increasing fitness, losing weight, getting out of the house, meeting people, even to enjoy a beautiful place. Each purpose might be suited by a slightly different kind of walkable place.

There are also walking purposes that are rarely discussed in the literature on walkability.

- One health-related form of walking is where people walk not for exercise but for restoration or stress reduction (often in a "natural" or vegetated setting) (Kaplan 1995). Typically, such environments are seen as restorative, relaxing, or recreational, but not "walkable" (For reviews see Maller et al. 2005; Wells et al. 2007; Bowler et al. 2010; Barton and Pretty 2010).

- In addition, walking may be incidental to some other purpose-perhaps called "being on your feet" rather than walking. For example, people caring for children or waiting on tables do a lot of walking, but the literature on walkability does not deal with such activities.

- Finally, much walking occurs indoors. Little of this makes it into the walkability discussion that is focused on the scale of the block, street, trail, and district.

It is unsurprising then that theories of walking are quite varied. Many urban design theories implicitly assume physical features will make people want to walk. However, the field of health has created a number of different theories of behavior change, many of which focus on personal characteristics, individual behaviors, and social contexts, with the physical environment only incidental (Baranowski et al. 2003). Where the environment is considered, it may be at a very small scale-in this literature, anything beyond the person is part of the environment, including such items as clothing. It may also focus on non-physical environments such as the social, media, or policy environments (Wells et al. 2007; Alfonzo 2005). 
This is an essential insight - that to create "walkable" places, block and neighborhood designs are not enough in themselves. Rather, other scales of the environment are also important (e.g. clothing), and other kinds of strategies need to be enlisted such as programming, pricing, and other policies. This might include restricting parking, making driving expensive, educating motorists, and/or providing supports to pedestrians (e.g. safe routes to school). Further, such factors as incomes, individual preferences, cultural values, and climate also affect walking. The same place may be more or less walkable, or have more or less actual walking, depending on such characteristics (Alfonzo 2005; Forsyth and Krizek 2010).

The nine themes or definitions are reflected in different kinds of planning and design for walkable environments. Some focus on specific components-for example, sidewalk, trail, crosswalk, signage, and signal design. However, at the larger level of the neighborhood or city, two main clusters of approaches contend for dominance in the area of physical community design (see Figure 3). On the one hand is the fine-grained multifunctional street pattern seen in compact city, New Urbanist, Jane-Jacobs-inspired, mixed-use, transit-oriented approaches that cluster people and destinations close together. This is typically in a grid or small block street pattern lined with sidewalks, but may take more organic forms based on historic city patterns. On the other side are the various forms of superblocks, where vehicular traffic is kept largely to the outside, or moves through with difficulty, and pedestrians infiltrate the center. In the current period this takes a number of forms, including college campuses, pedestrianized downtowns, the leafy Radburn-style designs of modernist high and low-rise superblocks, and even innovations like the fused grid (Southworth 1997; Lee and Ahn 2003; Lo 2009; Grammenos et al. 2008). 
Figure 3: Contrasting Community-Design Level Walkability Approaches

\author{
Relatively fine-grained, grid and \\ small block street pattern \\ Superblock walkability
}
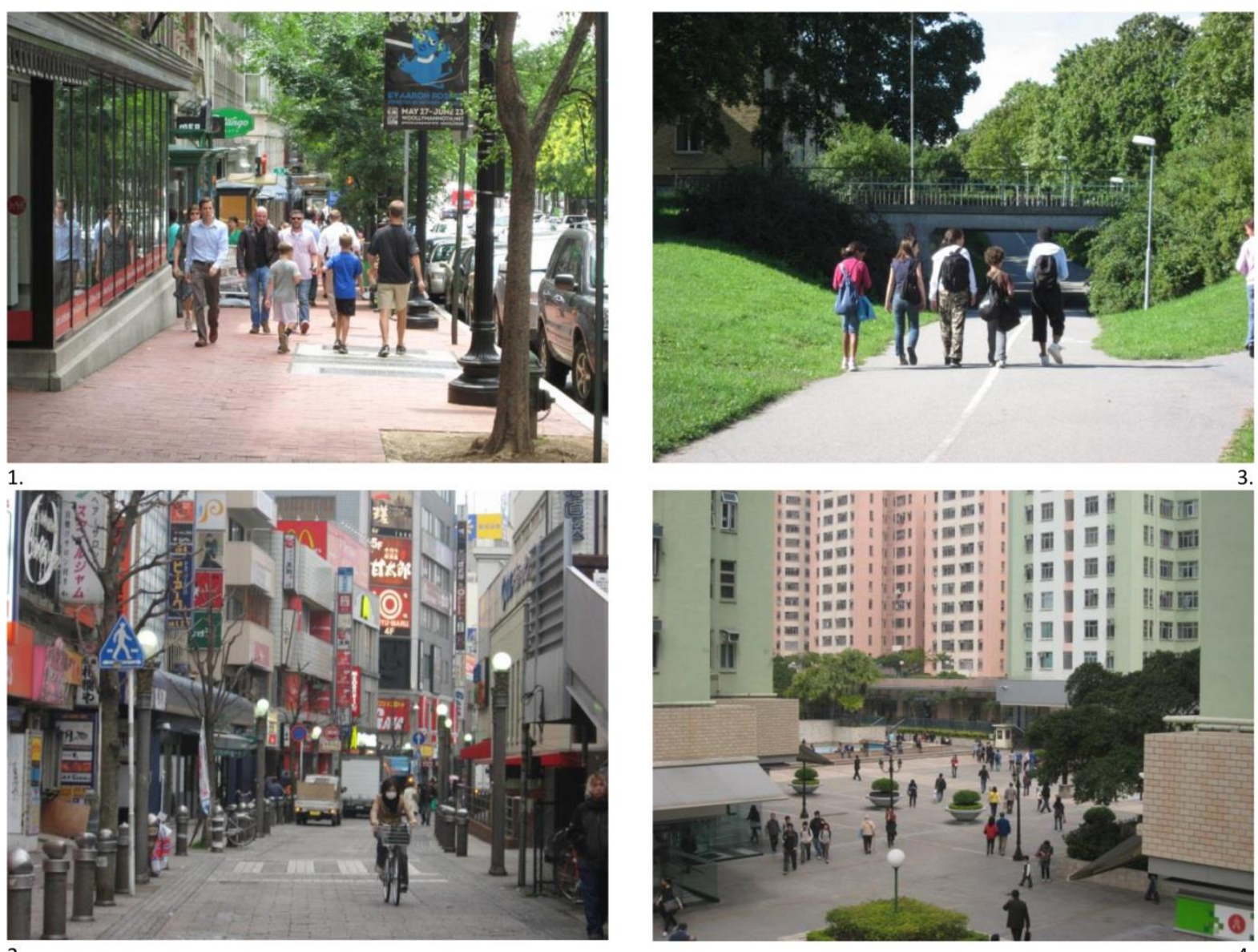

2.

Grid and small block: 1. With traditional footpath/sidewalk: Washington, DC, USA, 2. With shared street: Chiba, Japan

Superblock: 3. Low-density version: Stockholm, Sweden; 4. High density version: Hong Kong

Photos by author.

It is interesting that the grid/small block and superblock approaches emphasize some similar dimensions - such as traffic safety, personal safety, and sociability-and have both been touted as holistic solutions to urban problems. However, their designs are quite different in how they mix people and cars and in their emphasis on green space.Overall, a walkable place is a complex and contested phenomenon. The following section unpacks some of that complexity. 


\section{Nine Themes Unpacked \\ Conditions or means \\ Traversable}

According to the Oxford English Dictionary, walkability is not a word. Walkable is one, however. The first meaning, "Of terrain, a road, path, environment, etc.: that is suitable, fit, or safe for walkers," was in use by 1736 at least (Oxford English Dictionary 2014). This first definition of walkable places as traversable or suitable for walking turns out to be the main dictionary definition across a variety of sources. For example, Merriam-Websters (2015) defines walkable as "capable of or suitable for being walked" though one usage example they give is a "walkable distance" dealt with in the next theme.

The internet-based Dictionary.com is one of the few dictionaries to count walkability as a word-though the adjective "walkable" is the main form. This source is based on the older Random House Unabridged Dictionary as well as the American Heritage and Harper Collins dictionaries but it has its own lexicographers who can presumably keep abreast of current usage. For this source, being walkable combines the theme of condition with that of closeness (dealt with below): something that is walkable is "capable of being traveled, crossed, or covered by walking: a walkable road; a walkable distance" (Dictionary.com 2015, italics in original).

Walkability in this sense is about the very basic physical infrastructure to get from one place to another-is there a continuous path with some reasonable surface and no major hazards? This is in part about the quality of the path and in part about its configuration relative to origins and destinations, an issue of urban form (dealt with in many urban design literatures including aspects of space syntax and responsive environments) (Bentley et al 1985; Southworth 2006). What traversibility means will also vary with the walker's age, preferences, encumbrances such as strollers or packages, level of disability, weather, time of day, the attraction of the destination, perceived safety, other options available, hilliness, and numerous other factors. A literature on perceived walkability has investigated some of these personal differences (e.g. Gebel et al. 2009).

Traversability and the following two themes (compactness and safety) are related to a key purpose of walking: to get to a destination. This is a dominant view in transportation and an intuitive and commonsense definition. It does, however, omit many factors dealt with in later themes.

\section{Compact or Close}

A related but slightly different definition of a place being walkable is that destinations are close enough to get to in a reasonable time on foot. Thus the compact place-with a high density or proximity of destinations and people-is a walkable place. The second definition of walkable in the Oxford English Dictionary is of this genre. "Of a distance: that is short enough to be walked. Also of a place: close enough to be reached by walking" was in use by the end of the $18^{\text {th }}$ century (Oxford English Dictionary 2014). The Australian Macquarie Dictionary does not define walkable-except as being the adjective associated with the word walk-but does define a 
"walkable neighbourhood" as "a neighbourhood designed so that facilities, such as shops, parks, transport, etc., are within walking distance for most residents" (Macquarie Dictionary 2014).

Thus these definitions focus on distance to destinations, and closeness of complementary functions, including other modes of transport (Southworth 2006). For example, the neighborhood generator tool of the Australian Urban Research Infrastructure Network (2014) creates neighborhood polygons for "walkability analysis... based on the user supplied parameters of maximum distance along the network to traverse and a buffer value...." This kind of distance-based buffering approach is a very common way of assessing walkability (Brownson et al. 2009; Terzano and Morckel 2011, 96; Sohn et al. 2012).

More popular discussions also feature the issue of proximity. For example, an Irish Times article on "Making urban areas more walkable is a step towards fitness" paraphrases the words of a planner: "One of the major reasons for this [lack of walking and cycling], he says, is because of the poor design of pedestrian routes and the distances people have to travel to get to basic amenities such as schools, parks, shops, bus stops and work" (Irish Times 2013, 11).

Something that is compact in terms of having an intensity of activities or destinations within close proximity, however, also needs relatively direct and passable routes between those destinations (also raised in the prior theme). Thus definitions of walkability as compactness often go beyond distance to include some combination of residential density and land use mixture along with a measure of connectivity (block size, intersection density, measures of gridded vs. cul-de-sac street patterns, and the quality of paths). ${ }^{i \prime}$ Talen and Koschinsky (2013, 42 ), in a review of the literature on walkable neighborhoods, define walkability as comprising " geographical access as well as route quality,"Moudon et al's (2006) operational definition of walkability includes compactness (residential density, short distances to eating and drinking places) and small blocks for directness (see also Manaugh and El-Geneidy 2011; Porta and Renne 2005; Frank et al. 2009; Ozbil et al. 2011).

This issue of distance, destinations, and connectivity is also at the base of the walkscore.com algorithm, which as of early 2013, was based on street network distance to 9 destination types-e.g. restaurants, schools, and parks, and a penalty for big blocks and low intersection density (walkscore.com 2013a). This has become a very popular way of defining walkability, featured in venues from Good Housekeeping to the British Journal of Sports Medicine (Shapley 2014; Carr et al. 2011; Pivo and Fisher 2011).

This does raise questions. Exactly how compact a place needs to be and how close the destinations varies with a number of characteristics related to culture, perceptions, the level of attraction of the destination(s), and the ability to pay for alternative modes of transportation (Sohn et al. 2012; Methorst et al. 2010). It is also biased toward walking for transportation - to get somewhere-rather than recreation, although a number of definitions, including walkscore.com and some more academic approaches, do include recreational destinations (e.g. Giles-Corti et al. 2005). 
Safe

While safety is intimately related to other features of the walkable environment, it deserves a section of its own because the lack of safety is a key barrier to walking. This is true of safety from crime as well as traffic safety. When walkscore.com outlines the weaknesses of its algorithm, safety is involved in the first two items it mentions:

"There are a number of factors that contribute to walkability that are not part of our algorithm:

- Street design: Sidewalks and safe crossings are essential to walkability. Appropriate automobile speeds, trees, and other features also help.

- Safety from crime and crashes: How much crime is in the neighborhood? How many traffic accidents are there? Are streets well-lit?" (Walkscore.com 2014b)

While safety seems narrow as a definition, it is an important dimension in public and professional discussions. For example, it is key in the Complete Streets movement:

"Complete Streets are streets for everyone. They are designed and operated to enable safe access for all users. People of all ages and abilities are able to safely move along and across streets in a community, regardless of how they are traveling. Complete Streets make it easy to cross the street, walk to shops, and bicycle to work. They allow buses to run on time and make it safe for people to walk to and from train stations" (National Complete Streets Coalition 2014).

Safe Routes to School is an intervention also concerned with this issue, promoting both physical changes and programs (Stewart 2011).

In terms of defining walkability in terms of safety, the draft World Bank Global Walkability Index focuses centrally on safety and security. Of 14 measures generally in the areas of safety and security, convenience and attractiveness, and policy support, fully eight deal with safety (Krambeck and Shah 2006). Littman $(2014,1)$ distinguishes between "walking (the activity) and walkability (the quality of walking conditions, including safety, comfort and convenience)." The Federal Highway Administration's "Resident's Guide for Creating Safe and Walkable Communities" uses the terms "walkable" and "pedestrian-friendly" interchangeably (US. DoT FHWA 2013a, 2013b). While the publication focuses on several dimensions, including equity and physical activity (related to exercise and quality of life), it has a clear emphasis safety (see also Lyons et al. 2012). It provides a succinct definition of walkability that combines these dimensions:

"Definition: A walkable community is one where it is easy and safe to walk to goods and services (i.e., grocery stores, post offices, health clinics, etc.). Walkable communities encourage pedestrian activity, expand transportation options, and have safe and inviting streets that serve people with different ranges of mobility" (USDoT FHWA 2013, x).

An article from the Toronto Globe and Mail demonstrates the link between safety and walkability in a popular discussion:

"Toronto's walkability varies greatly, though, and in many parts of the city people on foot face a too-risky daily reality. Although pedestrian deaths have been cut in half in 
the last two decades, the number of people hit by vehicles remains stubbornly steady at around 2,200 annually" (Moore 2013, M4).

A walkable environment in terms of traffic safety has some combination of low traffic volumes or protection for pedestrians (buffers, signalized crosswalks, traffic calming, and the like) (Bike Walk Twin Cities 2013; Zeeger 1995). If crime is the lens, the focus is on a place perceived to be safe-well lit, without entrapment spots, perhaps free signs of disarray or of people perceived as threatening. One question is whether the most important factor is perceived safety or reported crime. The research findings are mixed (Foster and Giles-Corti 2008; Carver et al. 2008; Ding et al. 2011). Perceived safety is probably most important for walkability, though perceptions vary greatly with factors such as gender and social class (Lorenc et al. 2012).

One reviewer suggested that rather than traversibility and compactness, safety should be the basic requirement for walkability and it should go first. Which element is most important, and whether they should be placed in a hierarchy, is a fascinating question with perhaps no definitive answer. Notably, where people do present hierarchies of needs for walking, safety typically is not placed at the most basic level (e.g. Alfonzo 2005; Risser and Risser 2010; Mehta 2008). However, traversibility, the first in the list, does include a weak version of safety, being "suitable, fit, or safe for walkers" (Oxford English Dictionary 2014). Safety certainly deserves separate consideration.

\section{Physically-enticing}

A walkable community is often defined as something more than just traversable, compact, and safe but also rich in pedestrian-oriented infrastructure, including wide and well-maintained sidewalks, active street frontages, traffic calming measures, street trees and vegetated buffers, marked and signalized pedestrian crossings, benches, way-finding signage, and pedestrianscaled lighting (Al-Hagla 2012). It should have views to diverse buildings and open spaces. This makes the area interesting as well as convenient, drawing people to walk. Such a perspective is related to work by such authors as Jan Gehl (1987) and Jeff Speck (2012), however their emphasis is on environments that achieve the outcome of sociability in the next theme even if they create physically enticing environments to achieve that. In this theme the actual environment is front and center.

For example, the City of Geelong in Australia proposes the following definition of walkability: "Walkability is a quality of the built environment that invites people to get around on foot, not because they have to but because they will feel like they are missing out if they don't. ...A walkable community is far more than just a neighbourhood that makes walking possible. It needs to offer experiences to the walker that makes them want to walk. To do this the physical infrastructure needs to have characteristics that make people not just realise walking is possible but also that it is preferable to other modes of transport for at least some of their journeys" (David Lock Associates and City of Geelong 2008. 4; Healthy Spaces and Places 2009). 
Similarly, the measurement report in the lengthy European Pedestrians' Quality Needs study includes a definition of walkability in its core "assessment model for measuring walking", involving "Infrastructure \& public realm: features, qualities ("walkability")" (Sauter et al. 2010, 19). Southworth $(2006,247-248)$ proposes a complex definition including compactness and safety but physical enticement is a strong theme:

Walkability is the extent to which the built environment supports and encourages walking by providing for pedestrian comfort and safety, connecting people with varied destinations within a reasonable amount of time and effort, and offering visual interest in journeys throughout the network.

Southworth defines six components of urban design for walkability, with two relevant to this topic. First is "path context, including street design, visual interest of the built environment, transparency, spatial definition, landscape, and overall explorability." It also related to "path quality" that provides comfort and safety though infrastructure and design ${ }^{\mathrm{iii}}$

This is a definition of walkability prominent in the media and design professions. It assumes people are motivated to walk by certain forms of design - something that may be more true for some demographic groups, walking purposes, and regional locations (Leslie et al. 2007).

\section{Outcomes}

The next set of themes focus on outcomes thought to come from walkability.

\section{Lively and Sociable}

Walking for socializing or just to be out and about in a lively environment near other people has a long history - for example, window shopping or promenading. In these definitions, when someone says they are improving walkability or that a place is very walkable, they are referring to a general sense of liveliness, vitality, sociability, or vibrancy. They often refer to the work of Jane Jacobs (1961), William Whyte (1980), or Jan Gehl (1987) that has a more sociological view of good design and spatially they focus on commercial, mixed-use, or high-density residential areas. Walking may be quite slow-movement or physical activity is not the central aim. As Speck explains in his book Walkable Cities:

"Walkability is both an end and a means, as well as a measure. While the physical and social rewards of walking are many, walkability is perhaps most useful as it contributes to urban vitality and most meaningful as an indicator of that vitality....Get walkability right and so much of the rest [in terms of making cities more livable and successful] will follow" (Speck 2012, X).

Mehta's (2008, 238-239) work refining a hierarchy of walking needs places this dimension at the top as the "sense of belonging"; in addition, "presence of people and activities" is in Mehta's penultimate category called sensory pleasure. A secondary part of this literature relates to social connectedness and walkability, proposing that more walkable places have higher social capital or provide mental health benefits from interaction (Berke et al. 2007; Rogers et al. 2011). iv 
As Zook et al. propose in an article on smart growth and walkability, "Walkability and urban liveliness are not the same thing, nor does the presence of one guarantee the presence of other" (Zook et al. 2012, 232). For those using definitions related to this theme, however, there is a great deal of overlap.

\section{Sustainable Transport Option}

Walkability defined in terms of being a sustainable transportation option combines several key dimensions including economic, social, and energy use (Greenberg and Renne 2005). However the focus in this group of definitions is on transportation options.

In this area, walkability is typically proposed as an alternative to the car. An article in the ESRI newsletter Arc User provides such a definition related to transportation alternatives: "What Is Walkability? Walkability is a measure of the effectiveness of community design in promoting walking and bicycling as alternatives to driving cars to reach shopping, schools, and other common destinations" (Rattan et al., 2012). Greenberg and Renee $(2005,91)$ propose, in an article on neighborhood walkability and environmental justice, that the term walkable is a shorthand for environments that support walking, jogging, running, biking, in-line skating, and other nonmotorized forms of travel."

Some of these definitions are combined with other themes, though with transportation alternatives as a focus. For example, the U.S. National Oceanic and Atmospheric Administration's (2015) Coastal Waterfront and Smart Growth web site provides a range of instructions about development. Its fourth element is "Create walkable communities with physical and visual access to and along the waterfront for public use." At the very beginning, in the statement of principle, it proposes that "In a walkable community, trips by bicycle or on foot are viable transportation alternatives to the car." It goes on to mention several other dimensions including mixed use (compactness), safety, and infrastructure. However, it concludes its statement of this principle with "Walkable communities offer more transportation choices, higher levels of social interaction, greater opportunities for physical activity, and reduced emissions from automobile travel."

Overall, sustainability is a complex outcome. It may also be one of many dimensions in a more holistic definition.

\section{Exercise-Inducing}

The issue of the most supportive environments for walking outdoors and their relationships to exercise or physical activity is the area where researchers have spent a great deal of time over the past decade or so. In this work, the term walking may be used interchangeably with the term physical activity. However, physical activity is obviously broader, including work-related tasks, recreation and sports, household work, cycling, moving around in buildings, and the like. The big idea behind this work is to identify the specific dimensions of a walkable environment by examining where and how much people are walking. 
From this empirical work it can be seen that what counts as a walkable environment-in the sense of one that induces or at least supports exercise-is not the same for every person, purpose, or place. For example, in one of a number of recent systematic reviews Sugiyama et al. (2012) reviewed the literature to date and found that many studies identified associations between travel walking and destinations or land use mix. There were more modest associations with such factors as sidewalks and connectivity-results tended to vary between studies. Recreational walking had still more muted associations with environmental features-mainly recreational destinations and aesthetics of routes. Many of the aspects of environments perceived to enhance walkability, and which are reviewed elsewhere in this paper, were not found to increase the amount of actual walking (also Bauman et al. 2012). Logically, for example, places deemed "walkable" in one definition may be too convenient to allow much exercise (Van Dyck et al. 2009a; Lovasi et al. 2009; Gebel et al. 2009, 2011; Xu et al. 2010).

A core interest in this literature whether the increased transportation walking that people undertake in some kinds of more walkable locations can translate into increased overall physical activity. The results are complex. People certainly walk more for transportation in places with higher densities and accessible destinations. According to some systematic reviews of the literature, walking may increase total physical activity to a modest extent among all but older adults. However there may be a self-selection bias where people who want to walk move to "walkable" places, magnifying the effects of environment-the importance of this effect is much debated (McCormack and Sheil 2011; Cao et al. 2009). Does more walking reduce obesity? This is not as clear according to those same systematic reviews of research in both adults and children (Durand et al. 2011; Lee et al. 2008; Faulkner et al. 2009; Giles-Corti et al. 2009; Van Stralen et al. 2009; McCormack and Sheill 2011; Lubans et al. 2011; Van Cauwenberg et al. 2011; Bauman et al. 2012; Kerr et al. 2012; Wanner et al. 2012; Sugiyama 2012). This could be true because people who walk more, and who are more physically active, may also eat more.

\section{Proxy Definitions}

The final set of definitions use walkability as a term to represent places that are complex, rich, and well-designed. These draw together elements of prior themes but have prominence in public debates and in certain subfields of pedestrian planning and design.

\section{Multidimensional and Measurable}

This is a complex theme that obviously builds on prior categories. However, many definitional statements that start "walkability is" focus on it being multidimensional and state that those dimensions are measurable individually or combined into an index or indicator. Measuring walkability has become a thriving industry among researchers, practitioners, and the wider public which the success of Walkscore, described earlier, demonstrates. This is particularly the case in health, practice, and advocacy.

As the Centers for Disease Control and Prevention declare on the "Worksite Walkability" section of their web site, "Walkability is the idea of quantifying the safety and desirability of the walking routes." Talen and Koschinsky's (2013) review of the literature on walkable 
neighborhoods reflects this. They present three themes with the first being measurement (and the others criticism and assessment of benefits).Jane's Walk, an organization promoting the work of Jane Jacobs, has a similar approach: "Walkability is a quantitative and qualitative measurement of how inviting or un-inviting an area is to pedestrians" (Jane's Walk 2013).

Walkscore, one measure of walkability, is based on compactness and connectivity but many other definitions go much further, dealing with many more variables. As Pivo and Fisher (2011) state in an analysis of the (positive) effect of walkability on commercial real estate values and returns:

We define walkability as the degree to which an area within walking distance of a property encourages walking trips from the property to other destinations.... it is a multidimensional construct composed of different factors that together comprise a single theoretical concept. Contributing attributes include urban density, land use mixing, street connectivity (i.e., the directness of links and the density of connections), traffic volume, distance to destinations, sidewalk width and continuity, city block size, topographic slope, perceived safety and aesthetics. (Pivo and Fisher 2011, 186)

Similarly Lo's $(2009,163)$ paper exploring the issue of walkability concludes by partially defining it in terms of measures, specifically in terms of "factors that appear in a number of different walkability measures or metric[s]..." including sidewalk presence and maintenance, universal access, directness and connectivity, safety (at grade crossings, traffic, buffering), land use, landscaping, aesthetics, and security (perceived and actual crime). Leinberger and Alfonzo (2012) use the observational tool, the Irvine Minnesota Inventory, to propose a related list dealing with aesthetics, connectivity, density, form, pedestrian amenities, personal safety, recreational facilities, land uses, public spaces, and traffic measures (Leinberger and Alfonzo 2012, 6; also Boarnet et al. 2006; Day et al. 2006; Leinberger 2012). Some measures rely on perceptions. The Neighborhood Environment Walkability Scale (NEWS), later renamed Neighborhood Quality of Life Study survey (NQLS), asks respondents scores of questions about environmental features-housing types, other land uses, access to services, streets, places for walking and cycling, surroundings, and safety (Saelens et al. 2003; Cerin et al 2006). The appendix outlines a number of the measurement tools used in such studies.

The examples above are quite complicated lists of multiple items or questions. Other approaches create walkability indices or multidimensional scores. The World Bank's walkability index considers "the safety, security, economy, and convenience of traveling by foot" (Krambeck and Shah 2006; also Ewing and Handy 2009; Ewing et al. 2006; Ewing and Clemente 2013). Many of these indices and measures focus on walking for transportation, but there is a substantial subset examining recreational walking and tourism (Samarasekara et al. 2011; Boarnet et al 2011).

\section{Holistic solution}

Finally, walkability can be a proxy for better environments that generate investment, are more sustainable (in economic and social terms as well as environmental), and that are generally good places to be. As Talen and Koschinsky $(2013,43)$ outline in their review of the walkable 
neighborhood literature "The idea that a place (or neighborhood) should be "walkable" conjures up a pre- $19^{\text {th }}$ century, holistic view of health and well-being, combining notions of citizenship, civic life, democracy, resiliency, spiritual health, beauty, and social justice."

While such definitions may be seen by some as overly broad, they are commonly in use and are also the definitions most likely to stress the economic growth potential of walkability. The nonprofit organization Jane's Walk provides an example of this kind of definition, elaborating on an initial definition based on measurement and social vitality:

"Walkability is a quantitative and qualitative measurement of how inviting or un-inviting an area is to pedestrians. Walking matters more and more to towns and cities as the connection between walking and socially vibrant neighborhoods is becoming clearer. Built environments that promote and facilitate walking - to stores, work, school and amenities - are better places to live, have higher real estate values, promote healthier lifestyles and have higher levels of social cohesion.“ (Jane's Walk 2013)

This kind of definition is used by governments. As a promotional web site for Downtown Wilmington, NC states:

"Walkability is the cornerstone and key to an urban area's efficient ground transportation. Walkable communities put urban environments back on a scale for sustainability of resources (both natural and economic) and lead to more social interaction, physical fitness, diminished crime and other social problems. Walkable communities are more livable communities that lead to whole, happy, healthy lives for the people who live in them." (Downtown Wilmington 2013)

Common in practice-oriented sources, this kind of walkability is an indicator of better urban areas that attract redevelopment, population increase, and have high livability (Addison et al., 2013). This makes it an inclusive definition, but critics might say it is overly broad. It also avoids the question of incompatible outcomes of walkability, for example, if walkable places have higher housing costs they may have less vibrancy.

\section{What Next?}

This paper first traced the problem of defining walkability. Nine key themes or dimensions can be extracted from these definitions, including walkability as involving basic conditions or traversability, compact environments, high levels of personal safety, or physical enticement. Alternatively, walkability can be seen to promote outcomes such as liveliness, sustainable transport options, or exercise. Finally it is seen to be broadly about good design whether this is multidimensional and measurable or a way of about holistic solutions to various human problems.

In the remainder of the paper, I examine several implications of this diversity of themes, including how to clarify different types of walkability and the urban design and planning implications of the definitions.

\section{Clearer Definitions?}


Given the large differences in environmental features and outcomes associated with different approaches to walkability, there turn out to be many different kinds of walkable environments. Those who use the common idea-generating process of examining precedents to develop proposals for action may well draw on examples of walkable places that represent one definition that will simply not have the desired features or achieve the kinds of outcomes envisaged by another. This has substantial implications in that one may be designing an environment based on ideas about sociable walkable areas when the aim is to support increased exercise. Such a design may fail in its aim.

Can there be a shared definition of walkability? While a single definition is unlikely, it is useful to have clear, shared definitions to foster dialog and understanding.

Three possible ways forward frame options for shared definitions:

- Create a minimal definition of physical walkability focused on path condition/traversability and closeness with some basic level of safety-these are the core requirements for walking. Of course people can walk on remarkably rough surfaces and will walk fair distances to attractive destinations or to obtain exercise.

- Use specific terms for different kinds of walkable places related either to features (e.g. compact) or to outcomes (e.g. exercise-supporting places). The definitions would share a family resemblance (Wittgenstein 2009).

- Develop a comprehensive definition that moves beyond the kind of physical place that supports walking to also consider policies, programs, pricing, and people (demographics, preferences, perceptions, etc.). One idea is to create a kind of indicator out of the various dimensions or themes as has been done with sustainability and livability (Miller et al. 2013). However, this is difficult because some of the dimensions are at odds (e.g. closeness and exercise).

In the end perhaps the best that can be hoped for is more specificity in these debates.

\section{Walkable Places?}

A related issue is how does this affect the field of urban design? What sorts of interventions and places do each of the definitions lead to? Table 1 provides some insights. Key dimensions include infrastructure-both whether it is provided and its quality; the pedestrian network and accessibility of destinations; the kinds of activities that the place supports; and the kinds of policies and programs that help create the place and support the activity. Measures tap into what is important about that definition. At one end, a traversable place might have fairly minimal supports for walking and could be in a variety of contexts, and at the other end, walkability as a holistic solution is meant to create happy people and economically thriving districts. Overall, Table 1 demonstrates the differences among varying definitions of walkability in terms of design and planning strategies (like infrastructure, networks, and policy supports) and the measurable outcomes. 
Table 1: Walkability Themes and Examples of Related Interventions

\begin{tabular}{|c|c|c|c|c|c|}
\hline \multicolumn{6}{|l|}{$\begin{array}{l}\text { Interventions } \\
\text { (across) }\end{array}$} \\
\hline Themes (down); & $\begin{array}{l}\text { Infrastructure } \\
\text { provision }\end{array}$ & $\begin{array}{l}\text { Infrastructure } \\
\text { design/quality }\end{array}$ & $\begin{array}{l}\text { Pedestrian } \\
\text { network }\end{array}$ & Distances & Activities supported \\
\hline \multicolumn{6}{|l|}{$\begin{array}{l}\text { Environmental } \\
\text { Conditions }\end{array}$} \\
\hline Traversable & $\begin{array}{l}\text { Paths that are } \\
\text { relatively level, even }\end{array}$ & Basic level & $\begin{array}{l}\text { Relatively } \\
\text { complete }\end{array}$ & $*$ & $\begin{array}{l}\text { Being able to get } \\
\text { around at all on foot }\end{array}$ \\
\hline $\begin{array}{l}\text { Compact/ close } \\
\text { (destinations, } \\
\text { density, layout) }\end{array}$ & As above & Basic level & $\begin{array}{l}\text { Connected, } \\
\text { direct paths }\end{array}$ & Close destinations & $\begin{array}{l}\text { Getting to important } \\
\text { destinations }\end{array}$ \\
\hline Safe & $\begin{array}{l}\text { Separated paths, } \\
\text { safe crossings, traffic } \\
\text { calming }\end{array}$ & $\begin{array}{l}\text { Pedestrian-scaled } \\
\text { lighting, clear sight } \\
\text { lines }\end{array}$ & $\begin{array}{l}\text { Safe } \\
\text { links/crossings, } \\
\text { no movement } \\
\text { predictors }\end{array}$ & $*$ & $\begin{array}{l}\text { Getting around on } \\
\text { food without fear of } \\
\text { violence or accidents }\end{array}$ \\
\hline
\end{tabular}

\begin{tabular}{|c|c|c|c|c|c|}
\hline $\begin{array}{l}\text { Physically- } \\
\text { enticing }\end{array}$ & $\begin{array}{l}\text { Many paths, street } \\
\text { furnishings, } \\
\text { landscaping } \\
\text { treatments, human } \\
\text { scaled building }\end{array}$ & $\begin{array}{l}\text { Many aesthetically } \\
\text { pleasing elements }\end{array}$ & $\begin{array}{l}\text { Relatively } \\
\text { complete }\end{array}$ & * & $\begin{array}{l}\text { Both walking to } \\
\text { destinations and } \\
\text { recreational walking; } \\
\text { excitement }\end{array}$ \\
\hline
\end{tabular}

\begin{tabular}{|c|c|c|c|c|c|}
\hline \multicolumn{6}{|l|}{ Outcomes } \\
\hline $\begin{array}{l}\text { Lively and } \\
\text { sociable }\end{array}$ & Provided & Pedestrian scaled & $\begin{array}{l}\text { Relatively } \\
\text { complete }\end{array}$ & $\begin{array}{l}\text { Close to substantial } \\
\text { residential densities } \\
\text { and/or highly } \\
\text { accessible by } \\
\text { transit /car }\end{array}$ & $\begin{array}{l}\text { Shopping, cultural } \\
\text { activities, recreational } \\
\text { walking }\end{array}$ \\
\hline $\begin{array}{l}\text { Sustainable } \\
\text { transportation } \\
\text { option creating }\end{array}$ & Provided & Basic level & Complete & Close destinations & $\begin{array}{l}\text { Walking to } \\
\text { destinations; } \\
\text { alternative to car }\end{array}$ \\
\hline $\begin{array}{l}\text { Exercise- } \\
\text { inducing }\end{array}$ & Provided & $\begin{array}{l}\text { At least to a basic } \\
\text { level }\end{array}$ & Complete & $\begin{array}{l}\text { Close enough } \\
\text { (though not too } \\
\text { close!) }\end{array}$ & $\begin{array}{l}\text { Both walking to } \\
\text { destinations and } \\
\text { recreational walking }\end{array}$ \\
\hline \multicolumn{6}{|l|}{ Proxies } \\
\hline $\begin{array}{l}\text { Multidimensiona } \\
\text { I }\end{array}$ & $\begin{array}{l}\text { Sidewalks, lighting, } \\
\text { street trees, etc. }\end{array}$ & Measurable & $\begin{array}{l}\text { Complete, } \\
\text { connected }\end{array}$ & Close destinations & $\begin{array}{l}\text { Both walking to } \\
\text { destinations and } \\
\text { recreational walking }\end{array}$ \\
\hline Holistic solution & Provided & $\begin{array}{l}\text { Many aesthetically } \\
\text { pleasing elements }\end{array}$ & Complete & Close destinations & $\begin{array}{l}\text { Both walking to } \\
\text { destinations and } \\
\text { recreational walking }\end{array}$ \\
\hline
\end{tabular}

\footnotetext{
* Dimension less important in this theme.
} 


\section{Final Thoughts}

Better defining walkability has several benefits:

- It shows that walkable environments are not all the same. This is a key finding of this review.

- It illustrates the biases and assumptions in some popular definitions of walkability.

- It demonstrates that walkable environments for transportation and recreation purposes sometimes overlap but often do not.

- It highlights that while walkability is defined in multiple ways, some major purposes of walking - such as restoration and walking that is incidental to other activities - are not well covered by such definitions and risk being left out of debates.

Overall, urban designers and others interested in walkability could be more conscious about definitions. What is most walkable differs by walking purposes--whether people are walking to get somewhere, engage in exercise, socialize, or enjoy the outdoors, or if walking is part of some other activity such as looking after children or engaging in paid work. Those designing walkable environments have different aims. Those aims - such as creating a setting that has the minimum features for walking (paths, close destinations) vs. sociability or exercise-may well need different kinds of places to achieve. Walkability debates can be enriched by understanding these multiple dimensions. 


\section{Appendix}

Table 2 provides some examples of kinds of measurement tools used to either provide data for such multidimensional classifications or to create indices, highlighting whether such tools are likely to be used by researchers, practitioners, or the public. The number of such tools is enormous, making it impossible to be comprehensive (National Collaborative on Childhood Obesity Research 2013; National Cancer Institute. 2013; Brownson et al 2009). It should be noted that those items at the top of the table measure walkability and not walking. Relatively few walkability measures have been tested to see if they actually predict walking (Boarnet et al. 2011; Zook et al. 2012; Cerin et al. 2006; Rosenberg et al. 2009). ${ }^{v}$

Table 2: Domains of Measurement Tools for Walkability and Walking

\begin{tabular}{|c|c|c|c|}
\hline & Research & Practitioner & Public \\
\hline \multicolumn{4}{|l|}{ Measures of Walkability } \\
\hline \multicolumn{4}{|l|}{ Observations } \\
\hline Walkability audits & $\mathrm{xx}$ & $\mathrm{X}$ & $\mathrm{xX}$ \\
\hline Urban design audits & $x x$ & $x$ & \\
\hline School audits & $\mathrm{x}$ & $x x$ & $\mathrm{x}$ \\
\hline \multicolumn{4}{|l|}{ Computer-based and mechanical methods } \\
\hline Individual GIS measures of environments & $x x$ & $x$ & \\
\hline $\begin{array}{l}\text { Composite environmental scores or walkability } \\
\text { indices }\end{array}$ & $x x$ & $x$ & $x x$ \\
\hline \multicolumn{4}{|l|}{ Surveys (population and/or facility based) } \\
\hline $\begin{array}{l}\text { Surveys of perceived environmental } \\
\text { walkability }\end{array}$ & $x x$ & $x$ & $\mathrm{x}$ \\
\hline $\begin{array}{l}\text { Surveys of correlates (e.g. income) of } \\
\text { walkability }\end{array}$ & $x x$ & $x x$ & \\
\hline \multicolumn{4}{|l|}{ Measures of Walking } \\
\hline Pedestrian counts & $x$ & $\mathrm{x}$ & $x$ \\
\hline Surveys of actual walking (self-report, diaries) & $x x$ & $x$ & \\
\hline GPS tracking of actual routes & $x x$ & & $\begin{array}{r}x x \\
\text { urced) }\end{array}$ \\
\hline $\begin{array}{l}\text { Measures of movement (pedometer, } \\
\text { accelerometer) }\end{array}$ & $x x$ & & $\mathrm{x}$ \\
\hline
\end{tabular}




\section{Acknowledgments}

Thanks to the Urban Design International editors and several anonymous reviewers for comments on this piece.

\section{References}

Active Living Research. (2013) Tools and Measures: http://www.activelivingresearch.org/resourcesearch/toolsandmeasures, accessed 6 June 2013.

Addison C., Zhang S. and Coomes B. (2013) Smart growth and housing affordability: A review of regulatory mechanisms and planning practices. Journal of Planning Literature 28 (3): 215-257.

Alfonzo, M.A. (2005) To walk or not to walk: the hierarchy of walking needs. Environment and Behavior 37 (6): 808-836.

Al-Hagla, K.S. (2009) Evaluating New Urbanism's walkability performance: a comprehensive approach to assessment in Saifi Village, Beirut, Lebanon. Urban Design International 14: 139-151.

Australian Urban Research Infrastructure Network. (2014) Neighbourhood Generator. University of Melbourne. T http://docs.aurin.org.au/help/analysing-yourdata/walkability-tools/walkability001-points-to-regions/, accessed 6 June 2014.

Baranowski T., Cullen K.W., Nicklas T., Thompson D., and Baranowski J. (2003) Are current health behavioral change models helpful in prevention of weight gain efforts? Obesity Research 11: 23S-43S.

Barnett-Page, E. and Thomas J. 2009. Methods for the synthesis of qualitative research: a critical review. ESRC National Centre for Research Methods Working Paper. http://eprints.ncrm.ac.uk/690/1/0109\%2520Qualitative\%2520synthesis\%2520methods $\% 2520$ paper\%2520NCRM.pdf

Barton J. and Pretty J. (2010) What is the best dose of nature and green exercise for improving mental health? a multi-study analysis." Environmental Science and Technology 44 (10):3947-55.

Bauman A.E., Reis R.S., Rallis J.F., Wells J.C., Loose R.J.F. and Martin B.W. (2012) Correlates of physical activity: why are some people physically active and others not. Lancet 380: 258271.

Bentley I., Alcock A., Murrain P., McGlynn S., and Smith G.( 1985) Responsive Environments: A Manual for Designers. London: The Architectural Press.

Berke E.M., Gottleib L.M., Moudon A.V. amd Larson E.B. (2007) Protective association between neighborhood walkability and depression in older men. Journal of the American Geriatrics Society 55: 526-533.

Bike Walk Twin Cities. (2013) Infrastructure Solutions for Increased Walkability. http://www.bikewalktwincities.org/news-events/news/infrastructure-solutionsincreased-walkability, accessed 6 June 2013.

Boarnet M., Day K., Alfonzo M., Forsyth A., and Oakes J.M. (2006) The Irvine Minnesota Inventory to measure built environments: reliability tests. American Journal of Preventive Medicine 30 (2): 153-259. 
Boarnet, M., Forsyth, A., Day, K., and Oakes, J. M. (2011) Irvine Minnesota inventory short forms: Results of a predictive validity study. Environment and Behavior 43 (6): 735-775.

Booth A., Papaoannou D. and Sutton A. (2012) Systematic Approaches to a Successful Literature Review. Los Angeles: Sage.

Bowler, D. E., Lisette M. Ali B., Knight T.M. and Pulli A.S. (2010) A systematic review of evidence for the added benefits to health of exposure to natural environments. BMC Public Health 10 (1): 456.

Brownson R., Hoehner C., Day K., Forsyth A. and Sallis J. (2009) Measuring the built environment for physical activity: state of the art. American Journal of Preventive Medicine 36 (4s): s99-s123.

C.D.C. Healthier Worksite Initiative. (2013) Worksite Walkability. http://www.cdc.gov/nccdphp/dnpao/hwi/toolkits/walkability/index.htm, accessed 6 June 2013.

Callahan J. (2014) Writing literature reviews: a reprise and update. Human Resource Development Review 13 (3): 271-275.

Cao, X., Mokhtarian P.L., and Handy S.L. (2009) Examining the impacts of residential selfselection on travel behavior: A focus on empirical findings. Transport Reviews 29 (3): 359-395.

Caplan, N. and S. Nelson. (1973) On being useful: the nature and consequences of psychological research on social problems. American Psychologist 28 (3): 199-211.

Carr L.J., Dunsiger S.I. and Marcus B.H. (2011) Validation of Walk Score for estimating access to walkable amenities. British Journal of Sports Medicine 45: 1144-1148.

Carver A., Timperio A. and Crawford D. (2008) Playing it safe: the influence of neighborhood safety on children's physical activity-a review. Health and Place 14: 217-227.

Cerin E., Saelens B., Sallis J.F. and Frank L.F. (2006) Neighborhood Environment Walkability Scale: Validity and development of a short form. Medicine and Science in Sports and Exercise 38 (9): 1682-1691.

Charlier Associates, Krizek K. and Forsyth A. (2012) The Colorado Mile Markers: Recommendations for Measuring Active Transportation. Colorado: Kaiser Permanente.

Chaskin R. (1997) Perspectives on neighborhood and community: a review of the literature. Social Service Review 71 (4): 521-547.

Dannenberg, A.L., Cramer T.W. and Gibson, C.J. (2005) Assessing the walkability of the workplace: A new audit tool. American Journal of Health Promotion 20 (1): pp. 39-44.

David Locke Associates and City of Geelong. (2008) Clause 56 Walkability Toolkit. http://www.geelongaustralia.com.au/common/Public/Documents/8cd9bd471204de4Walkability\%20Toolkit.pdf

Day K., Boarnet M., Alfonzo M., Forsyth A. (2006) The Irvine Minnesota Inventory to measure built environments: development. American Journal of Preventive Medicine 30 (2): 144152.

Dictionary.com (2015a) Overview. http://content.dictionary.com/, accessed 6 March 2015.

Dictionary.com (2015b) Walkability. http://dictionary.reference.com/browse/walkability, accessed 6 March 2015.

Ding D., Sallis J.F., Kerr J., Lee S. and Rosenberg D.E. (2011) Neighborhood environment and physical activity among youth: a review. American Journal of Preventive Medicine 4 (4): 442-445. 
Dixon-Woods M., Cavers D., Agrawal S., Annandale E., Arthur A., Harvey J., Hsu R., Katbamna S., Olsen R., Smith L., Riley R. and Sutton A. 2006. Conducting a critical interpretive synthesis of the literature on access to healthcare by vulnerable groups. BMC Medical Resesarch Methodology 6 (35): http://www.biomedcentral.com/1471-2288/6/35

Downtown Wilmington. (2013) A Walkable Downtown. http://www.wilmingtondowntown.com/live/a-walkable-downtown, accessed 6 March 2015.

Durand C.P., Andalib M., Dunton G.F., Wolch J.and Pentz M.A. (2011) A systematic review of built environment factors relates to physical activity and obesity risk: implications for smart growth urban planning. Obesity Reviews 12: e173-e182.

Evans D. and Kowanko I. (2000) Literature reviews: Evolution of a research methodology. Australian Journal of Advanced Nursing 18 (2): 33-38.

Ewing R. and Handy, S. (2009) Measuring the unmeasurable: Urban design qualities related to walkability. Journal of Urban Design 14 (1): 65-84.

Ewing R. and Clemente, O. (2013) Measuring Urban Design: Metrics for Livable Places. Washington, DC: Island Press.

Ewing R., Handy S., Brownson R.C., Clemente O. and Winston E. (2006) Identifying and measuring urban design qualities related to walkability. Journal of Physical Activity and Health 3 (S1): S223-S240.

Faulkner G.E., Buliung R.N., Flora P.K. and Fusco C. (2009) Active school transport, physical activity levels and body weight of children and youth: a systematic review. Preventive Medicine 48 (1):3-8.

Florida R. (2010) America's most walkable cities. The Atlantic December 15: http://www.theatlantic.com/business/archive/2010/12/americas-most-walkablecities/67988/, accessed 6 March 2015.

Forsyth A. and Krizek, K. (2010) Promoting Walking and Bicycling: Assessing the Evidence to Assist Planners. Built Environment 36 (4): 429-446.

Forsyth, A. (2012) Defining Suburbs. Journal of Planning Literature 27 (3): 270-281.

Forsyth, A. and Southworth, M., (2008) Cities afoot-pedestrians, walkability, and urban design. Journal of Urban Design 13 (1): 1-3.

Frank L.D., Sallis J.F., Saelens B.E., Leary L., Cain K, Conway T.L. and Hess P.M. (2010) The development of a walkability index: Application to the Neighborhood Quality of Life Study. British Journal of Sports Medicine 44: 924-933.

Gebel K., Bauman A. and Owen N. (2009) Correlates of non-concordance between perceived and objective measures of walkability. Annals of Behavioral Medicine 37: 228-238.

Gebel K., Bauman A.E., Sugiyama T. and Owen N. (2011) Mismatch between perceived and objectively assessed neighborhood walkability attributes: Prospective relationships with walking and weight gain. Health and Place 17: 519-524.

Gehl J. (1987) Life Between Buildings: Using Public Space. New York: Van Nostrand Reinhold.

Giles-Corti B., Broomhall M., Knuiman M., Collins C., Douglas K., Ng K., Lange A. and Donovan R. J. (2005) Increasing walking: how important is distance to, attractiveness, and size of public open space?. American Journal of Preventive Medicine 28 (2):169-176 
Giles-Corti B., Kelty S.F., Zubricj S.R. and Villanueva K.P. (2009) Encouraging walking for transport and physical activity in children and adolescents: How important is the built environment? Sports Medicine 39 (12): 995-1009.

Grammenos F., Craig B., Pollard D., and Guerrera C. (2008) Hippodamus rides to Radburn: A new model for the $21^{\text {st }}$ Century. Journal of Urban Design 13 (2): 163-176.

Greenberg M.R. and Renne J. (2005) Where does walkability matter the most? An environmental justice interpretation of New Jersey data. Journal of Urban Health: Bulletin of the New York Academy of Medicine 82 (1): 90-100.

Healthy Spaces and Places. (2009) Case Study-Geelong Walkability Toolkit. http://www.healthyplaces.org.au/userfiles/Geelong\%20Walkability\%20Toolkit\%20June 09.pdf

Hodge, D. and Lacasse, J.. (2011) Ranking disciplinary journals with the Google Scholar H-Index: A new tool for constructing cases for tenure, promotion, and other professional decisions. Journal of Social Work Education 47 (3): 579-596.

Irish Times. (2013) Making urban areas more walkable is a step towards fitness; Suburban areas hostile to pedestrians need retrofit design to promote walking. June 25, 11.

Jacobs, J. (1961) The Death and Life of Great American Cities. New York: Random House.

Jane's Walk. (2013) Walkability: Making cities welcoming, liveable and safe. http://www.janeswalk.net/index.php/walkability/, accessed 6 March 2015.

Kaplan S. (1995) The restorative benefits of nature: toward an integrative framework. Journal of Environmental Psychology 15: 169-182.

Kerr J., Rosenberg D. and Frank L. (2012) The role of the built environment in healthy aging: Community design, physical activity, and health among older adults. Journal of Planning Literature 27 (1): 43-60.

Krambeck H. and Shah J. (2006) The Global Walkability Index: talk the walk and walk the talk. The World Bank. http://cleanairinitiative.org/portal/sites/default/files/60499_paper.pdf

Lee C.-M. and Ahn K.-H. (2003) Is Kentlands better than Radburn? The American garden city and New Urbanist paradigms. Journal of the American Planning Association 69 (1): 50-71.

Lee M.C., Orenstein M.R. and Richardson M.J. (2008) Systematic review of active commuting to school and children's physical activity and weight. Journal of Physical Activity and Health $5(6): 930-49$.

Leinberger C. and Alfonzo M. (2012) Walk this way: The economic promise of walkable places in metropolitan Washington DC. Washington, DC: Metropolitan Policy Program.

Leinberger C. (2012) Now coveted: A walkable, convenient place. New York Times May 25, http://www.nytimes.com/2012/05/27/opinion/sunday/now-coveted-a-walkableconvenient-place.html?_r=0.

Leslie E., Saelens B., Frank L., Owen N., Bauman A., Coffee N. and Hugo G. (2005) Residents' perceptions of walkability attributes in objectively different neighborhoods: a pilot study. Health and Place 11: 227-236.

Leslie E., McRea R., Cerin E. and Stimson R. (2007) Regional variations in walking for different purposes: The South East Queensland Quality of Life Study. Environment and Behavior 39: 557-577.

Littman T.A. (2003) Economic value of walkability. Transportation Research Record 1828: 3-11. 
Littman T.A. (2014) Economic value of walkability. Victoria Transportation Policy Institute: http://www.vtpi.org/walkability.pdf

Lo, R.H. (2009) Walkability: what is it? Journal of Urbanism 2 (2): 145-166.

Lorenc T., Clayton S., Neary D., Whitehead M., Petticrew M., Thomson H., Cummins S., Sowden A. and Renton A. (2012) Crime, fear of crime, environment, and mental health and wellbeing: mapping review of theories and causal pathways. Health and Place 18: 757765

Lovasi G.S., Grady S. and Rundle A. (2012) Steps forward: Review and recommendations for research on walkability, physical activity, and cardiovascular health. Public Health Reviews 33 (4): 484-506.

Lovasi G.S., Neckerman K.M, Quinn J.W., Weiss C.C. and Rundle A. (2009) Effect of individual or neighborhood disadvantage on the association between neighborhood walkability and Body Mass Index. American Journal of Public Health 99: 279-284.

Lubans D.R., Boreham C.A., Kelly P. and Foster C.E. (2011) The relationship between active travel to school and health-related fitness in children and adolescents: a systematic review. International Journal of Behavioral Nutrition and Physical Activity 8 (1): 5.

Lyons W., Peekett H., Morese L., Khurana M. and Nash L. (2012) Metropolitan Area Transportation Planning for Healthy Communities. Cambridge MA: John A. Volpe National Transportation Systems Center.

Macquarie Dictionary. (2014) Walkable neighborhood. http://www.macquariedictionary.com.au/, accessed 6 August 2014.

Maller C., Townsend M., Pryor A., Brown P. and St. Leger L. (2005) Healthy nature healthy people: Contact with nature as an upstream health promotion intervention for populations. Health Promotion International 21 (1): 45-54.

Manaugh K. and El-Geneidy A.M. (2011) Validating walkability indices: how do different households respond to the walkability of their neighbourhood. Transportation Research Part D 16 (4): 309-315.

McCormack G. and Shiell A. (2011) In search of causality: a systematic review of the relationship between the built environment and physical activity among adults. International Journal of Behavioral Nutrition and Physical Activity 8: 125.

http://www.ijbnpa.org/content/8/1/125

Mehta V. (2008) Walkable streets: pedestrian behavior, perceptions, and attitudes. Journal of Urbanism 1 (3): 217-245.

Merriam-Webster Dictionary. (2015) "Walkable": http://www.merriamwebster.com/dictionary/walkable, accessed 6 August 2015.

Methorst R., Monterde i Bort H., Risser R., Sauter D., Tight M. and Walker J. (Eds.) (2010) Pedestrians' Quality Needs. Final Report of the COST project 358, Cheltenham: Walk21. http://www.walkeurope.org/final_report/default.asp

Miller H.J., Witlox F. and Tribby C.P. (2013) Developing context-sensitive livability indicators for transportation planning: a measurement framework. Journal of Transport Geography 26: 51-64.

Moore, O. (2013) A step toward safer streets; Inspired by innovations in Chicago and other cities, Toronto is starting to take a pedestrian-first approach to its thinking about its roads. The Globe and Mail June 8, M4. 
Moudon A.V., Lee C., Cheadle A.D, Garvin C., Johnson D., Schmid T.L, Weathers D. and Lin L. (2006) Operational definitions of walkable neighborhood: theoretical and empirical insights. Journal of Physical Activity and Health 3:S99-S117.

National Cancer Institute. (2013) Standardized Questionnaires of Walking and Bicycling Database: http://appliedresearch.cancer.gov/tools/paq/, accessed 6 March 2013.

National Collaborative on Childhood Obesity Research. (2013) Measures Registry: http://tools.nccor.org/measures/, accessed 6 March 2013.

National Complete Streets Coalition. (2014) Fundamentals. http://www.smartgrowthamerica.org/complete-streets/complete-streetsfundamentals, accessed 6 April 2014.

National Oceanic and Atmospheric Administration, U.S. (2015) Coastal and Waterfront Smart Growth Element 4. http://coastalsmartgrowth.noaa.gov/elements/walkable.html, , accessed 6 August 2015.

Oxford English Dictionary. (2014) Walkable http://www.oed.com/view/Entry/225243?isAdvanced=false\&result=6\&rskey=LOgugl\&), accessed 6 April 2014.

Ozbil, A., Peponis J. and Stone, B. (2011) Undertanding the link between street connectivity, land use, and pedestrian flows. Urban Design International 16: 125-141.

Pivo $G$ and Fisher G. (2011) The walkability premium in commercial real estate investments. Real Estate Economics 39 (2): 185-219.

Porta, S. and Renne, J. L. (2005) Linking urban design to sustainability: formal indicators of social urban sustainability field research in Perth, Western Australia. Urban Design International 10: 51-64.

Rattan A., Campese A. and Eden C. (2012) Modeling Walkability. ArcUser Winter:

http://www.esri.com/news/arcuser/0112/modeling-walkability.html

Risser R. and Risser C.C. (2010) Some thoughts about needs from a psychological perspective. In: Methorst R., Monterde i Bort H., Risser R. Sauter D., Tight M. and Walker J. (Eds.) Pedestrians' Quality Needs. Final Report of the COST project 358, Cheltenham: Walk21. http://www.walkeurope.org/uploads/File/publications/PQN\%20Final\%20Report\%20par t\%20B5-nw.pdf

Rogers, S.H., Halstead J.M. Gardner K.H. and Carlson C. H. (2011) Examining walkability and social capital as indicators of quality of liked at the municipal and neighborhood scales. Applied Research in Quality of Life 6: 201-213.

Rosenberg D., Ding D., Sallis J.F., Kerr J. Normal G.J., Durant N. Harris S.K. and Saelens B.E. (2009) Neighborhood Environment Walkability Scale for youth (NEWS-Y): Reliability and relationship with physical activity. Preventive Medicine 49: 213-218.

Saelens, B.E., Sallis, J.F., Black, J.B. and Chen, D. (2003) Neighborhood-based differences in physical activity: An environment scale evaluation. American Journal of Public Health, 93: 1552-1558.

Samarasekara G.N., Fukahori K. and Kubota Y. (2011) Environmental correlates that provide walkability cues for tourists: an analysis based on waling decision narrations. Environment and Behavior 43 (4): 501-524.

Sauter D., Hogerts C., Tight M., Thomas R. and Zaidel D. (2010) Measuring walking. In: Methorst R., Monterde i Bort H., Risser R. Sauter D., Tight M. and Walker J. (Eds.) Pedestrians' 
Quality Needs. Final Report of the COST project 358, Cheltenham: Walk21.

http://www.walkeurope.org/uploads/File/publications/PQN\%20Final\%20Report\%20par t\%20B4.pdf

Shapley D. (2014) The 15 most walkable cities in America. Good Housekeeping http://www.goodhousekeeping.com/family/travel/most-walkable-cities-460708\#sli

Sohn D.W., Moudon A.V. and Lee J. 2012. The economic value of walkable neighborhoods. Urban Design International 17 (2): 115-128.

Southworth M. (1997) Walkable suburbs? An evaluation of neotraditional communities at the urban edge. Journal of the American Planning Association 63 (1): 28-44.

Southworth M. (2005) Designing the walkable city. Journal of Urban Planning and Development December 246-257.

Speck, J. (2012) Walkable City. New York: Farrar, Strauss and Giroux.

Stewart O. (2011) Findings from research on active transportation to school and implications for Safe Routes to School programs. Journal of Planning Literature 26, 2: 127-150.

Sugiyama T., Neuhaus M., Cole R., Giles-Corti B. and Owen N. (2012) Destination and route attributes associated with adults' walking: a review. Medicine and Science in Sports \& Exercise 44 (7): 1275-1286.

Talen E. and Koschinsky J. (2013) The walkable neighborhood: A literature review. International Journal of Sustainable Land Use and Urban Planning 1 (1): 42-63.

Terzano K. and Morckel V. (2012) Walk or bike to a healthier life: Commuting behavior and recreational physical activity. Environment and Behavior 43 (4): 488-500.

U.S. Department of Transportation, Federal Highway Administration. (2013a) A Resident's Guide for Creating Safe and Walkable Communities. http://safety.fhwa.dot.gov/ped_bike/ped_cmnity/ped_walkguide/about.cfm

U.S. Department of Transportation, Federal Highway Administration. (2013b) Resource Sheet 3: Identifying Pedestrian Safety Concerns Using a Walkability Audit. http://safety.fhwa.dot.gov/ped_bike/ped_cmnity/ped_walkguide/resource3.cfm

Van Cauwenberg J. De Bourdeaudhuij I., De Meester F., Van Dyck D., Salmon J., Clarys P. and Deforche B. (2010) Relationship between the physical environment and physical activity in older adults: A systematic review. Health and Place 17: 458-469.

Van Dyck D., Cardon G., Deforche B. and De B ourdeaudhuij I. (2009a) Lower neighbourhood walkability and longer distance to school are related to physical activity in Belgian adolescents. Preventive Medicine 48: 516-518.

Van Dyck, D., Deforche, B., Cardon, G. and De Bourdeaudhuij, I. (2009b) Neighbourhood walkability and its particular importance for adults with a preference for passive transport. Health and Place 15: 496-504.

Van Stralen M.M., de Vries H., Mudde A.N., Bolman C. and Lechner L. (2009) Determinants of initiation and maintenance of physical activity among older adults: a literature review. Health Psychology Review 3: 147-207.

Walkscore.com. (2013a) Walk Score Web site. Methodology. http://www.walkscore.com/methodology.shtml, accessed 6 March 2013. 
Walkscore.com. (2014b) How It Doesn't Work: Known Issues with Walk Score. http://www.walkscore.com/how-it-doesnt-work.shtml

Wanner M., Gotschi T., Martin-Diener E., Kahlmeier S. and Martin B. (2012) Active transport, physical activity, and body weight in adults: a systematic review. American Journal of Preventive Medicine 42 (5): 493-502.

Wells N.M., Ashdown S.P., Davies E.H.S., Cowett F.D. and Yang Y. (2007) Environment, design, and obesity: opportunities for interdisciplinary collaborative research. Environment and Behavior 39 (1): 6-33.

Whyte W. (1980) Social Life of Small Urban Spaces. Washington, DC: Conservation Foundation. Williams, R. (1976) Keywords. New York: Oxford.

Wittgenstein, L. (2009) (orig. 1953) Philosophical Investigations. 4th ed. P.M.S. Hacker and J. Schulte eds. and trans. Oxford: Wiley-Blackwell.

Xu F., Li J., Liang Y., Wang Z., Hong X., Ware R.S. et al. (2010) Associations of residential density with adolescents' physical activity in a rapidly urbanizing area of Mainland China. Journal of Urban Health 14, 1: 44-53.

Zegeer C. V. (1995) Design and Safety of Pedestrian Facilities. Washington. DC: Institute of Transportation Engineers.

Zook J.B., Lu Y., Glanz K. and Zimring, C. (2012) Design and pedestrianism in a smart growth development. Environment and Behavior 44, 2: 215-234. 
'This lack of clarity is of course not only a problem with the term walkability. Other reviews have found similar problems with the terms "community," "culture," and "neighborhood" in sociology and "suburbs" within urban studies (Hillery 1955; Williams 1976; Chaskin 1997; Forsyth 2012).

ii Alfonzo (2005), in one of the more sophisticated approaches to walking, proposes a hierarchy of transport and recreational walking needs mainly related to environmental and social features. The first is level is feasibility which is more personal; the second is accessibility (which includes the first two themes in this paper among other factors). The other needs are safety, comfort, and pleasurability dealt with in later themes. See Mehta (2008) for a revision of this hierarchy.

iii Southworth's six dimensions of a walkable environment include path connectivity, "links to other modes, safety, path quality, and path context (2006, 249).

iv Bauman et al. (2012), in a review of reviews, of a related question, found that results are inconclusive as to whether more walking is done in places where with a positive social environment. Of course this is different to the idea that walkable places produce other health benefits like social connections.

v However, many measures of walkability have been tested for reliability, particularly those used in health research (Active Living Research 2013; National Cancer Institute 2013; National collaborative on Childhood Obesity Research; Charlier Associates et al. 2012; Brownson et al., 2009). 